Archives de sciences sociales des religions

123 | juillet - septembre 2003

Varia

\title{
The Internal Popular Discourse of Israeli Haredi Women
}

Kimmy Caplan

\section{(2) OpenEdition}

1 Journals

Electronic version

URL: http://journals.openedition.org/assr/1069

DOI: $10.4000 /$ assr.1069

ISSN: $1777-5825$

Publisher

Éditions de l'EHESS

Printed version

Date of publication: 1 July 2003

Number of pages: 77-101

ISBN: 2-222-96737-6

ISSN: 0335-5985

\section{Electronic reference}

Kimmy Caplan, «The Internal Popular Discourse of Israeli Haredi Women », Archives de sciences sociales des religions [Online], 123 | juillet - septembre 2003, Online since 25 October 2005, connection on 30 April 2019. URL : http://journals.openedition.org/assr/1069; DOI : 10.4000/assr.1069 
Arch. de Sc. soc. des Rel., 2003, 123 (juillet-septembre) 77-101

Kimmy CAPLAN

\section{THE INTERNAL POPULAR DISCOURSE OF ISRAELI HAREDI WOMEN (1)}

\section{Introduction}

In July 1994, a new lampoon was circulated on the walls of Mea Shearim and Geulah, two well-known Haredi neighborhoods of Jerusalem. The public announcement, entitled "Great Warning," focused on the rising phenomenon of male preachers who speak to female audiences, and male and female speakers who appear before women. Signed by the rabbinical authorities of the "Eda Haredit," a right-wing extreme anti-Zionist group within the Haredi community (2), this lampoon condemned these gatherings, prohibited them from taking place, and demanded that if a man does speak to a female audience - there should be a partition between him and his audience. According to their view, men and women preaching in the same gathering is absolutely prohibited.

The leaders of the "Eda Haredit" are concerned with the growing trend in mainstream Haredi society of men who speak to female audiences, but make no reference to another popular phenomenon - that of women lecturing and preaching to

(1) This article is a chapter in a comprehensive study on popular religion in Israeli Haredi society, and it is based upon two lectures: The first at the Department of Sociology and Anthropology, Tel-Aviv University, 4.6.1998, and the second at an International Workshop on « Resurgent Religious Movements and Violence ", Helsinki, 19.6.2001. Most of the audiotaped materials cited are located at the Harvard College Library, Harvard University, Cambridge (Mass.), and marked with the letters HCL. Unmarked audiotapes are in the author's possession. I thank the staff of the Jewish Division of the Widener Library at Harvard for their ongoing assistance and patience. This project would have never materialized without several research grants from the following institutions: The Hadassah Research Institute on Jewish Women, Brandeis University, Waltham (MA), 2000; The Fanya Gottesfeld Heller Center for the Study of Women, Bar-Ilan University, Ramat-Gan, 2001; and The Van Leer Jerusalem Institute, Jerusalem, 2001-2002; Finally, I received invaluable assistance and constructive criticism at various stages from Gideon Aran, Sarit Barzilai, Elisheva Baumgarten, Richelle Budd Caplan, Renee Levine Melammed, Chaim I. Waxman, the anonymous readers on behalf of this journal, and especially Emmanuel Sivan, for which I am most grateful.

(2) For partial important details on this group, see: Menachem Friedman, Society and Religion: The Non-Zionist Orthodox in Eretz-Israel-1918-1936, Jerusalem, Yad Ben Zvi, 1977 [Hebrew], pp. 47, 70, $73,85,134,140$. 
women. Every week there are tens of women's gatherings throughout Haredi-populated cities and neighborhoods, who get together in order to listen to male and/or female speakers. The popular female figures include, among others: Simah Akrib, Alona Einstein, Peninah Elkarif, Hayah Feldman, Berakhah Gabai, Ester Greenberg, Lea Kook, Rivah Lapidot, Heniah Schiff, Noah Yaron, and Yocheved Zinwert. To the best of my knowledge, this is an unprecedented phenomenon in the history of Jewish Orthodoxy, and it presents us with a unique case study in examining the role of women in fundamentalist societies. Finally, it sheds light on several aspects of popular religion and culture in Israeli Haredi society.

Some of the topics discussed in these sermons and lectures addressed to women would be considered "traditional" and "conventional." For example, instruction of ritual laws pertaining to women, including Sabbath preparation and observance as well as purity and dietary laws or "domestic religion (3)," ethics (4), and personal stories of women who returned to the faith (5). However, other topics focus on "controversial" and delicate issues, such as: family planning, the role of the Haredi woman, the relationship between men and women, domestic responsibilities and work outside the home. Furthermore, certain parts of these discussions on "controversial" topics include feminist notions and concepts, which we would not expect in an ultraconservative society - a phenomenon that has been uncovered among newly Orthodox women in America (6).

Focusing on the popular discourse on three central "controversial" issues: understanding the opposite sex, women's work outside the home, and family purity laws, this article raises some general and preliminary observations and characteristics of this contemporary popular phenomenon, suggests some conclusions, and, primarily, lays the ground for further discussion and research.

\section{Methodological considerations}

Israeli Haredi society is composed of dozens of groups and subgroups, such as Hasidim and Mitnagdim, Ashkenazim and Sephardim, political parties and organizations, and a set of subgroups and institutes: yeshivot (talmudic academies),

(3) On a semi-related Israeli cultural contact, see: Susan S. SERED, Women as Ritual Experts: The Religious Lives of Elderly Jewish Women in Jerusalem, New York-Oxford, Oxford University Press, 1992, pp. 87-103.

(4) Tamar EL-OR, Educated and Ignorant: Ultraorthodox Jewish Women and Their World, Boulder-London, L. Rienner, 1994, esp. pp. 89-135. Titles of audiotapes include: Zisah HAZAN, «A Series on the Laws of Evil Tongue » [Hebrew] (6 tapes); Rivah LAPIDOT, "The Quality of Confidence [in God] » [Hebrew]; Heniah SchifF, "Guarding of the Tongue » [Hebrew] (a series of lectures); Yocheved ZINWERT, «Love Thy Neighbour as Thyself » [Hebrew].

(5) Hear, for example: Gali AhAroni, « A Personal Story: On My Way to Happiness » [Hebrew]; Simah AKRIB, «A Personal Story: I Place God in Front of Me » [Hebrew]; Alona EInsteIn, " A Personal Story » [Hebrew]; Anat Cohen, " A Personal Story: On My Way to Happiness » [Hebrew].

(6) Debra R. Kaufman, «Paradoxical Politics: Gender Politics Among Newly Orthodox Jewish Women in the United States » in Valentine M. Moghadam, ed., Identity Politics and Women: Cultural Reassertions and Feminisms in International Perspective, Boulder-San Francisco-Oxford, Westview Press, 1994, pp. 349-367. 
Hasidic courts, and various affiliation groups (7). It is impossible to cover all these groups, often in strife, and therefore this study relates primarily to mainstream Ashkenazi Haredim though it touches upon Sephardi Haredim as well (8). This, since the women's gatherings tend to have a diverse mainstream Haredi audience, and the popular sources tend to be listened to and read by women from various groups.

The Israeli Haredi reality is unique in various ways. Unlike European countries and America, Israel is a developed country in certain aspects and a developing one in others, and this has a major impact on its Haredi community. For example, whereas many Haredim in America and in certain European countries are considered middle class economically, the majority of Israeli Haredim are defined as lower or lower-middle class. In addition, living in a welfare state and under laws which connect between the working force and army service by privileging people who served in the army (the vast majority of Israeli Haredim do not serve in the army), are both unique to the Israeli scene.

Consequently, it is quite complicated, although possible, to suggest a comprehensive comparative perspective, but this requires a series of additional studies, which, to the best of my knowledge, do not exist. Therefore, this paper focuses on Israeli Haredi society, the most central and biggest of its kind in the world, and it does not attempt to present a comparative study of Haredi communities in America, Europe, South Africa or Australia.

Nevertheless, certain comparative perspectives are raised with regard to American Haredim, which represent the second largest Haredi community. The importance of the European Haredi communities in France, which has the largest Jewish population in Western Europe, as well as in Belgium, England and Switzerland, is unquestionable. These Haredi communities have strong ties with certain groups within Israeli Haredi society, such as the North African Jews of France with Sephardi Haredim in Israel, and the extreme anti-Zionist Haredim in England with their allies in Jerusalem.

Notwithstanding these important and yet unresearched European connections, we hold that the most fruitful comparative perspective concerning Haredi women's discourse is with the American Haredi scene. This, due to the diverse connections and influences between Israeli and American Haredim in this topic, which are evident, for example, in the identical popular literature published in both languages.

Our primary interest is the internal discourse of Israeli Haredi women, be the speaker male or female. The fact that female speakers take a significant role in this discourse should not be taken for granted, since it is an unprecedented phenomenon

(7) See, for example: Ilan Greilsammer, Israel: Les Hommes en Noir, Paris, Fondation Nationale des Sciences Politiques, 1991; Samuel C. HeIlman and Menachem Friedman, "Religious Fundamentalism and Religious Jews: The Case of the Haredim » in Martin E. MarTy and R. Scott ApplebY, eds., Fundamentalisms Observed, Chicago-London, Chicago University Press, 1991, pp. 197-265; Aviezer Ravitzky, Messianism, Zionism, and Jewish Religious Radicalism, Chicago-London, Chicago University Press, 1996.

(8) This, based upon the fact that the audiotaped sources discussed are utilized, for the most part, in these segments, thereby leaving out extreme groups such as the "Eda Haredit" and certain Hasidic courts. For some of the methodological problems and challenges concerning the scholarly use of Haredi audiotaped sermons and lectures, see: Kimmy CAPLAN, "God's Voice: Audiotaped Sermons in Israeli Haredi Society », Modern Judaism, 17(3), 1997, pp. 253-280. 
in Israeli Haredi society. There are important differences in both style and content between male and female speakers and preachers addressing women, but these characteristics are beyond the scope of this work.

When dealing with family issues, most of this internal discourse focuses on the ideal-type family in which the husband devotes his time to learning sacred texts, and the wife works in order to provide financial support. However, as we shall see, there are many Haredi families in which the husband does not learn all or even part of the day, and in others women do not work. Therefore, the fact that the internal public discourse rarely addresses those who do not fit this ideal-type is important in itself.

There is Haredi literature that targets a relatively small and learned population, but the extent to which it trickles down to the public, if at all, is unclear. In contrast, the sources discussed below are clearly classified as popular literature. They are aimed at the ordinary woman, and therefore express the outlook and beliefs of their authors and the dilemmas of this society.

When dealing with popular sources, we encounter several complicated methodological problems that demand special caution (9). For example, popular sources are not always systematic, and oral sources are even less orderly and tend to be more associative than the written word. Furthermore, in order to assess the importance and centrality of any popular source, we must take into considerations the sensitivity of the topic at hand, the extent of recurrence of the remarks, the intended audience, and the degree of popularity of the authors or speakers. The following discussion is concerned primarily with issues and themes that appear repeatedly in the internal popular discourse of Haredi women.

Finally, the author of this paper is a male and due to the strict segregating norms and rules in Haredi society regarding mixed audiences of men and women, he is unable to attend many live lectures and sermons delivered to Haredi women. This segregation is part of a fundamental emphasis on keeping the sexes as separate as possible, as of age three, if not earlier, and distinguishing between them by various formative religious rituals (10). Therefore, the following discussion is based primarily upon audiotaped and printed materials, and relies strongly on content analysis.

(9) For a thorough methodological discussion of popular religion and beliefs, see: David D. HALL, Worlds of Wonder, Days of Judgment: Popular Religious Belief in Early New England, Cambridge (MA), Harvard University Press, 1989, pp. 3-21.

(10) See, for example: Yoram BiLu, «Circumcision, the First Haircut and the Torah: Ritual and Male Identity Among the Ultraorthodox Community of Contemporary Israel » in Mai GHoussouB and Emma Sinclair-Webb, eds., Imagined Masculinities: Male Identity and Culture in the Modern Middle East, London, Saqi, 2000, pp. 33-65. 


\section{Women and fundamentalisms, women in fundamentalisms}

With the exception of the aforementioned book of Tamar El-Or (11), the internal discourse of Israeli Haredi women has barely received scholarly attention (12). Therefore, before describing this phenomenon, we must place it in several contexts that are somewhat different from the framework suggested by El-Or.

Several works have focused on the place of women in fundamentalist groups and the complex relationship between fundamentalism and gender (13), uncovering a number of basic issues that seem to be applicable to gender-related topics in Haredi societies. The basic notion which seems to be common in all fundamentalist societies is the fact that men are superior, whereas women are inferior; men assume the responsibility for providing for their families and women run the households and raise the children; men make decisions - with or without the women's input. Many of these approaches are based upon the understanding that biological and physical differences between the sexes have direct implications on all levels of family life.

This may be a simple framework when analyzing the ideological and theological approaches presented by fundamentalist groups and individuals, which provide us with the "ideal type" family, gender roles and male-female relationships in general. However, the reality and challenges of modern life make it virtually impossible to live in accordance with these ideals (14). This, for example, is the case with regard to women being an important, at times vital, part of the working force in

(11) EL-OR, Educated and Ignorant, op. cit.

(12) Additional works include: Menachem Friedman, The Haredi Woman, Jerusalem, The Jerusalem Institute for Israel Studies, 1988 [Hebrew]; Idem, "The Ultra-Orthodox Woman » in Yael Azmon, ed., A View into the Lives of Women in Jewish Societies: Collected Essays, Jerusalem, Zalman Shazar Center, 1995 [Hebrew], pp. 273-291; Shlomit OrYan, "'Modest Language - Humble Souls': Speech Patterns among Israeli Orthodox Women and Girls ", Hebrew Linguistics 41-42, 1997 [Hebrew], pp. 7-20; Deborah Weissman, « The Education of Religious Girls in Jerusalem During the Period of British Rule: The Crystallization and Institutionalization of Five Educational Ideologies », Ph.D. Thesis, The Hebrew University of Jerusalem, 1993 [Hebrew].

(13) Nancy T. Ammerman, Bible Believers: Fundamentalists in the Modern World, New Brunswick-London, Rutgers University Press, 1987, pp. 134-147; Margaret LAMBerTs BEndroth, Fundamentalism and Gender, 1875 to the Present, New Haven-London, Yale University Press, 1993; Helen HARDACRE, "The Impact of Fundamentalisms on Women, the Family, and Interpersonal Relations » in Martin E. Marty and R. Scott Appleby, eds., Fundamentalisms and Society: Reclaiming the Sciences, the Family, and Education, Chicago-London, Chicago University Press, 1993, pp. 129-151; Shahla HAERI, "Obedience versus Autonomy: Women and Fundamentalism in Iran and Pakistan ", Idem, pp. 181-214; Jorge E. MaldonAdo, «Building 'Fundamentalism' from the Family in Latin America », Idem, pp. 214-240; Andrea B. Rugh, "Reshaping Personal Relations in Egypt », Idem, pp. 151-181.

(14) Erika FrIEDL, «Ideal Womanhood in Postrevolutionary Iran » in Judy BRINK and Joan Mencher, eds., Mixed Blessings: Gender and Religious Fundamentalism Cross Culturally, New York-London, Routledge, 1997, pp. 143-158. 
fundamentalist America (15), in Israeli and American Haredi societies (16), and in Egypt, Iran, Pakistan (17), and Sudan (18).

The gap between ideal frameworks and reality creates numerous tensions surrounding women's roles in fundamentalist societies. In light of this situation, religious systems and spiritual leaders seek to provide answers, explanations and solutions to explain this gap and reality (19). The need to encounter influences and consequences of modernity lead fundamentalist societies to devote considerable attention to women's roles in the context of the tensions between obedience and autonomy; submission and influence; occupation versus career; and women as dangerous sex symbols on the one hand, and their holy role as childbearers, nurturers and educators on the other. This continuous encounter results in complex and changing perceptions over time as to what exactly these terms mean (20).

Another tenuous issue is the role of women in religious life in general and their place in religious worship in particular. For example, debates over defining women's roles in fundamentalist religious institutions and the question whether or not women should serve as preachers and pastors remain unsolved and controversial issues among certain fundamentalist groups in America for several decades (21). With regard to women preachers and preaching, Bendroth concludes, "though fundamentalists might countenance the occasional female preacher, they were not out to encourage the practice (22)." In addition, "Dispensationalists referred to women preachers, especially those in Pentecostal traditions, with deep scorn. (23)" For example, in the eyes of Bishop Johnson of "The Church of The Lord Jesus Christ of the Apostolic Faith" in Philadelphia, "God has never called and sent a woman to preach the gospel and never will... every woman preacher is

(15) Ammerman, Bible Believers, p. 137.

(16) El-Or, Educated and Ignorant, op. cit.; Friedman, The Haredi Woman, op. cit.

(17) Haeri, «Obedience versus Autonomy », op. cit., pp. 194-195; Val MoghadAM, "Women, Work, and Ideology in the Islamic Republic », International Journal of Middle East Studies, 20 (2), 1988, pp. 221-243; Valentine M. Moghadam, Women, Work, and Economic Reform in the Middle East and North Africa, Boulder-London, L. Rienner, 1998, pp. 153-179. Since their husbands were soldiers during the Iran-Iraq war, many Iranian women went to work for economic reasons. During this lengthy war, many men died and others became handicapped. This situation increased the financial burden on women. Moreover, there were national needs to be filled, such as production of arms. After joining the working force, many women did not want to stop working despite demands from some religious leaders in Iran.

(18) Sondra Hale, «Ideology and Identity: Islamism, Gender, and the State in Sudan » in BrinK and Mencher, eds., Mixed Blessings, op. cit., pp. 117-143.

(19) Ammerman, Bible Believers, op. cit., p. 139; Rugh, "Reshaping Personal Relations in Egypt », op. cit., pp. 170-176.

(20) On submission, see: R. Marie Griffith, God's Daughters: Evangelical Women and the Power of Submissiom, Berkeley, University of California Press, 1997, pp. 169-186, 196-198.

(21) BENDroth, Fundamentalism and Gender, pp. 73-97. There are interesting parallels between the debates over women being pastors and those regarding ordaining women as rabbis, a delicate issue in American-Jewish religious movements for several decades. The most heated Jewish debate occurred in the Conservative movement during the late 1970s-early 1980s. Beth S. Wenger, "The Politics of Women's Ordination: Jewish Law, Institutional Power, and the Debate over Women in the Rabbinate » in Jack Wertheimer, ed., Tradition Renewed: A History of the Jewish Theological Seminary of America, New York, The Jewish Theological Seminary of America, 1997, vol. 2, pp. 483-525.

(22) BENDROTh, Fundamentalism and Gender, op. cit., p. 27.

(23) Ibid, p. 146. On Shi'a women preachers in Pakistan, see: Mary E. Hegland, « A Mixed Blessing: The Majales - Shi'a Women's Rituals of Mourning in Northwest Pakistan » in BRINK and MENCHER, eds., Mixed Blessings, op. cit., pp. 186-187. 
lost of and on her way to destruction because she is deceived of the devil and lied on God (24)."

In sensitive issues of this nature semantics become of great importance, as has been demonstrated regarding the objection to relate to women's words as sermons and to accept them as preachers - even though a form and content analysis does not show any significant difference between their "speeches" and the sermons of male preachers (25). To put it simply, preaching is a religious profession designated for men, not women, and, therefore, preaching a sermon is something men do and not women. (26) This seems to be the case in contemporary Israeli Haredi society, in which we observe a strong tendency to relate to women who speak in public as lecturers and not as preachers.

\section{Israeli Haredi women - setting the stage}

The grounds for the rising internal discourse of Haredi women lay in the Haredi reality of life in Israel, especially in families in which the husband is a full-time yeshivah or kolel (talmudic academy for married men) student. The income of such families depends highly on government support, which comes primarily from child allowance (paid by the National Insurance Institute, according to the number of children (27)) and institutional funds (in form of stipends). In addition, women's salaries are an important part of the Haredi monthly household

(24) Bishop S.C. Johson, "Who is this that Defies and Challenges the Whole Religious World on these Subjects? », Burning Subjects, 21, Philadelphia: n.d., pp. 12-14.

(25) Beverly M. Kienzle and Pamela J. Walker, eds., Women Preachers and Prophets through Two Millenia of Christianity, Berkeley-Los Angeles-London, University of California Press, 1998, Preface, esp. p. xiv; Elaine J. LAWLess, Handmaidens of the Lord: Pentecostal Women Preachers and Traditional Religion, Philadelphia, University of Pennsylvania Press, 1988, pp. 11-14.

(26) For some works on women preaching and preachers, see: Catherine A. BREKUS, Strangers and Pilgrims: Female Preaching in America, 1740-1845, Chapel Hill-London, The University of North Carolina Press, 1998; Rebecca LARSOn, Daughters of Light: Quaker Women Preaching and Prophesying in the Colonies and Abroad, 1700-1775, New York, Alfred A. Knopf, 1999; Elaine J. Lawless, Preaching Revolution: Calling for Connection in a Disconnected Time, Philadelphia, University of Pennsylvania Press, 1996; Deborah M. VALEnZe, Prophetic Sons and Daughters: Female Preaching and Popular Religion in Industrial England, Princeton, Princeton University Press, 1985.

(27) Child allowance is paid by the National Insurance Institute since 1959. As of 1965, the sums are paid on a monthly basis for every child, until he/she reach age 18 . The payments are progressive (i.e. for every additional child the family receives more than it did for the previous child). The criteria of families eligible have undergone many changes over the years, the details of which we will not address at this point. Overall, with few exceptions, since 1975 child allowance is paid for all children, notwithstanding the family's financial situation or other considerations. During the years 2002-2003 several laws as well as a comprehensive economic plan of the government led to several decreases in the amounts paid per child. For the most recent example, in July 2003 a family with one child before 31.5 .2003 received NIS (= New Israeli Shekels) 146, and in August they received NIS 144; for three children, the family received NIS 581 in July and NIS 483 in August; and for six children, NIS 2615 in July and NIS 1981 in August. The plan is to continue to decrease child allowance gradually until 2009, by which time families will receive an identical amount for each child NIS 144. A family of five children that received NIS 1981 in May 2003 will receive NIS 720 in 2009. This already has serious financial ramifications on numerous Haredi families which have five or more children. 
income, especially among families in which the husband learns in a yeshivah or kolel (28).

For example, between 1979 and 1982 the salaried income in a Haredi family in which the male was a non-participant in the labor force (i.e. student) was 33.3 percent, out of which the husband earned 1.5 percent and the wife -31.8 percent. Between 1993 and 1996, the salaried income in the same type of family was 17.8 percent of the monthly household income, out of which the wife's salary was 17.2 percent. (29) Notwithstanding the decline in the percentage of income from salary over the years (30), women continue to earn almost one hundred percent of the family income from salary.

Most mainstream Haredi women learn in the Beit Ya'akov educational system, which, in the 1950s and 1960s concentrated on producing teachers for the Haredi schooling system. Since the 1970s the range of topics taught at Beit Ya'akov is gradually more diverse and women can gain training in various other occupations, in addition to numerous institutions, which provide training for Haredi women in fields such as computers and secretarial work.

Due to this society's demographic growth, it could not supply work opportunities for all these women within the Haredi society. As a result, we evidence over the last twenty to thirty years, a growing number of Haredi women who are working in non-Haredi companies and institutions as secretaries, computer workers, kindergarten and school teachers, and in the food industry. Overall, Haredi women who work among a majority of non-Haredi workers tend to hold correct, functional and at times cordial relationships with their colleagues, but in most cases, these do not develop into strong social ties.

Although possible correlations between Haredi women's occupations and their geographic location have not been explored, preliminary observations lead us to suggest that differences exist in this respect between Haredi centers and peripheral communities due to the opportunities available locally.

Most working Ashkenazi Haredi women come from Mitnagdic as well as certain Hasidic circles, although other Hasidic groups, such as Gur and some of the extreme and most segregating groups, are relatively more hesitant, limiting and strict regarding women joining the working force.

Israeli Haredi society of the 1990s includes many women who are working in jobs, which have the potential of developing into careers. Some Haredi women are holding their jobs for twenty and even thirty years, and have been recognized, appreciated and promoted. This, as we shall see, explains the emphasis of the internal popular discourse on career aspects in addition to those regarding work.

(28) For data on the numbers of yeshivah and kolel students, their family's income and its analysis, see: Eli Berman, Sect, Subsidy and Sacrifice: An Economist's View of Ultra-Orthodox Jews, Jerusalem, The Jerusalem Institute for Israel Studies, 1998, pp. 13-19; Idem, « Subsidized Sacrifice: State Support of Religion in Israel », Contemporary Jewry, 20, 1999, pp. 167-201, esp. p. 184; Varda SHIFFER, "The Haredi Educational System: Allocation of Public Funds », Idem, pp. 143, 157-160. The relative numbers of full-time yeshivah students in Haredi communities around the world are by far lower than in Israel. See, for example: Amiran Gonen, From Yeshiva to Work: The American Experience and Lessons for Israel, Jerusalem, The Floersheimer Institute for Policy Studies, 2000 [Hebrew], p. 20.

(29) Berman, Sect, Subsidy and Sacrifice, op. cit., pp. 13-14.

(30) Which is explained, in part, by the rise of income from child allowance as well as from institutional funds. 
As we have noted, Haredi women's gatherings have become a popular phenomenon over the last two decades. These gatherings are for women only, and they vary in time, location, content, and other variables. In most cases, men are not allowed to attend. During these special events, which often take place in synagogues during hours when there are no official prayers, women sit in the area designated for men due to its larger seating capacity. Occasionally, one will find men sitting in the women's section of synagogue. The separation between the sections, a crucial matter for Orthodox and Haredi Jews in general, and specifically at times of prayer, allows men to clandestinely sit in the "balcony" and hear the lecture or the sermon given to a female audience without being seen by the women. This reverse situation is further illuminated when a male who has a question will write it on a note and pass it down to a female sitting in the audience, who will subsequently address it to the speaker.

Due to the availability and configuration of the synagogue, this is a convenient place to hold such gatherings, however, they also take place in other venues, such as public halls and girls' schools. The audience can number between a few dozen and several hundreds. Mass gatherings of thousands do exist, but the scope of their audience, aims and atmosphere create certain dynamics that are not conducive to in-depth discussions on any given topic.

The frequency of these gatherings ranges from those which take place on a regular basis, usually once a week/fortnight, or once a month, to those that are one-time programs. In addition, there are series of lectures which are given by either professionals with academically recognized degrees, such as family counselors, educators, and psychologists, or those perceived as professionals, who have gained an informal reputation within the community over the years. This type of lecture series usually consists of six to ten meetings at fixed times and places, each one devoted to another aspect of the general topic. For example, there is a series of eight undated lectures by Rabbi Simhah Cohen on "Communication in the Family," in which the speaker addresses related topics, such as "Feelings and Compliments," Dialogue in Marriage," "Criticism in Marriage," and "To Give, to Take and to Say Thank You (31)."

Many of these gatherings are audiotaped and reproduced for mass consumption. They can be bought, for affordable prices, in shops or borrowed under certain conditions in special audiotape libraries and private collections, tens of which exist in Jerusalem alone. The market of audiotaped sermons and lectures consists of at least seven thousand titles at any given moment, and the turnover, especially of the most popular speakers and preachers, is high. The use of these audiotapes is widespread and covers most, if not all, groups and sub-groups within Israeli Haredi society.

Finally, these gatherings shed light on the internal discourse within Haredi society. Members of the audience in our case are usually Haredi women or those

(31) Simhah CoHEN, «Family Communication » [Hebrew] (HCL, JSCA 24 [1-8]). Hear also Peninah ELKARIF, « Marriage: A Personal Challenge and a Fundamental Factor in Building the Personality of the Partners » [Hebrew] (HCL, JSCA 26 [1-6]); Hayah Feldman, « The Jewish House » [Hebrew] (13 lectures) designated for married women only; Esther GREENBERG's twelve lectures on "The Holiness of the Jewish Home "; and Rivah LAPIDOT, "The Holiness of the Jewish Home » [Hebrew] (HCL, JSC 189 [901-908]). 
returning to the faith, and this is the case regarding those listening to the audiotapes as well (32). The vast majority of these discussions are not aimed at the "other" Israelis and do not reach them. Therefore, with the exception of a few cases, we cannot dismiss the issues discussed as rhetoric aimed at the general public or as an expression of external apologetics.

\section{Understanding the opposite sex: a new trend ?}

Since the 1960s, one of the main messages of the feminist movement, as well as gender research, is that men and women have "different voices (33)." The huge gap between them is classically described in terms of human beings coming from different planets (34). According to this view, gender differences do not reflect upon women's abilities, but rather should be perceived as a tool to improve the way men and women understand, relate and communicate with each other.

To the best of my knowledge, Israeli Haredim did not publicly address the subject of "understanding the opposite sex" until the 1980s, and if they did - it was not as widespread and popular. To be sure, this society always had, and still has, rabbis, preachers and educators who gained a reputation of being sensitive and capable of helping married couples work out their difficulties, but this remained an intimate issue between the sides involved. In addition to marriage counseling, since the 1980s, we evidence a continuous rise in popular-public discourse regarding "understanding the opposite sex."

It should be noted that certain parts of American-Haredi society have been dealing publicly with feminist issues and certain outcomes of feminist approaches, since the 1960s. For example, Jewish women who returned to religion (hozerot biteshuvah) and joined the Habad movement, came with feminist views and, years later, employed their knowledge in order to challenge feminism and publish counter-feminist literature (35). This is probably connected to the fact that "many of the leaders and theorists of the 1960s feminist movement had been Jews (36)," and should be seen in light of evangelical and fundamentalists" "deep shock" as a result of the 1970s feminist movement (37). Furthermore, while engaging in feminism,

(32) Although the existence of audiotapes enables men to listen to lectures and sermons designated for women only. See: CAPLAN, «God's Voice», op. cit., p. 258.

(33) Carol Gilligan, In a Different Voice: Psychological Theory and Women's Development, Cambridge (MA)-London, Harvard University Press, 1982.

(34) John GraY, Men are from Mars, Women are from Venus: A Practical Guide for Improving Communication and Getting What You Want in Your Relationships, New York, Harper and Collins, 1992.

(35) Debra R. Kaufman, «Engendering Orthodoxy: Newly Orthodox Women and Hasidism » in Janet S. Belcove-Shalin, ed., New World Hasidim: Ethnographic Studies of Hasidic Jews in America, Albany, State University of New York Press, 1995, pp. 135-161; Bonnie J. MorRIs, Lubavitcher Women in America: Identity and Activism in the Postwar Era, Albany, State University of New York Press, 1998, pp. 100-123; 127-135.

(36) Joyce AntLer, The Journey Home: Jewish Women and the American Century, New York-London, Free Press, 1997, p. 260. For a detailed description and analysis, see pp. 259-285.

(37) Susan F. Harding, The Book of Jerry Falwell: Fundamentalist Language and Politics, Princeton, Princeton University Press, 2000, p. 179. 
some of these women found themselves developing stronger ties with Jewish tradition and religious life, and set the ground for certain religious changes (38).

Returning to the Israeli-Haredi scene, a great deal of attention has been given in recent years to the following questions: How should one deal with both women's and men's self-images of the family and their partners? How can one gain a better understanding of his/her spouse ? How can this improve the relationships between them? Several male and female popular speakers and preachers discuss these issues in rising frequency, and a growing number of books offering practical guidance from "choosing a mate" to married life and raising children, addressing both men and women, have appeared in recent years, in both Hebrew and English (39).

Some of the topics discussed in these sources present basic principals and general guidelines, such as "The Challenge of Acceptance," "The True Meaning of Love," "The Key to Unity," "Creating an Atmosphere," and "Quality Time (40)." Other sources relate to specific situations and practical questions that are perceived as common among Haredi married couples. Examples include "The Right Approach to Anger," "How to Act When a Dispute Arises in the Family ?," "Stress [in the house] on Friday Evening [before the Sabbath begins]," "Visiting the Parents - Who's First? [his or her parents]," "When a Woman Prepares Food for Her Husband, How Will She Know if it is to His Taste," "How to Behave When Guests are Around (41)," and the proper approach of the husband to his wife's job and the help he should provide in order to fulfill domestic obligations (42). It is important to emphasize that most of these issues are not unique to Haredim and occupy non-Haredi and non-Jewish discussions of ways to achieve successful marriage.

The popular books and manuals on the market are addressed to both men and women. The attention of each sex is drawn to the other's sensitivities and points of view, in order to supply an understanding of what the "other" goes through in certain stressful situations, the right approach needed in order to handle them, and ways to dissolve tension. For example, the Abramovs' book, Two Halves of a Whole, which is divided into two main parts, "On Being a Wife" and "On Being a Husband." Addressing the awareness and expectations of both sexes, and not only those of women, seems to be a new trend in Israeli Haredi society.

Occasionally, male speakers who address both men and women find the need, when addressing women, to point out that they tell men the same things that they tell women. For example, in his first lecture in a series of presentations to a female

(38) Idem, pp. 285-309.

(39) See, for example: Yirmiyohu and Tehilla Abramov, Two Halves of a Whole: Torah Guidelines for Marriage, Southfield, Targum Press, 1994 (Hebrew ed.: Shenayim Shehem Ehad: Hanehayot Lehayei Hanisuin Al Pi Hatorah, Jerusalem and New York, Feldheim, 1996); Shaul ButBikah, Calmness in Your Castle, Benei Berak: n.p., 1993 [Hebrew]; Simhah CoHen, What Did You Say ?: Making Yourself Understood in Marriage - A Jewish Perspective, Benei Berak: n.p., 2000 (Based upon his Hebrew two-volume Habayit Hayehudi [=The Jewish Home], n.p., 1995-1997); S. EisendlatT, Fulfillment in Marriage: A Comprehensive Guide for Making Your Marriage a Success Story, Jerusalem, Feldheim, 1988 (Hebrew ed.: Hayim Shel Osher, Jerusalem, 1987, 2 parts); Baruch E. GoldshmidT, Good Wisdom: On Matters of Conducting the Home, Jerusalem: n.p., 1997 [Hebrew]; Yehudah LeBovits, Shidduchim and Zivugim: The Torah's Perspective on Choosing Your Mate, Southfield, Targum Press, 1987; Avigdor Miller, Career of Happiness: True Joy in the Home, Brooklyn, Yeshiva Gedolah Bais Yisroel, 2000; B. TeBARdowitz, With Wisdom She Builds Her Home, Ramla, Hish, 1997 [Hebrew] (associated with Habad).

(40) Abramov, Two Halves of a Whole.

(41) Butbikah, Calmness in Your Home, op. cit; Goldshmidt, Good Wisdom, op. cit.

(42) CoHen, The Jewish Home, 2, op. cit., pp. 57-87. 
audience, Rabbi Simhah Cohen, a Haredi marriage counselor, states that "I also feel uncomfortable at this point that this is for women and I don't want you to feel that, God forbid, I am trying to condemn. No, I just have no choice; there is no point for me to condemn the men here. When I see them, I condemn them (43)."

The fact that these issues have become part of the public-popular discourse does not mean that every topic is perceived suitable for public discussion. Certain "intimate" issues remain in the private domain, or, at least, their potential audience should be controlled and restricted as much as possible. For example, in chapter nine of the second part of their book, which is addressed to men, the Abramovs discuss "Achieving Holiness" in sexual intercourse. Based upon the Talmud, they focus on nine "frames of mind which should not be present at the time of [sexual] relations." Their presence "can be devastating to the relationship [between the couple]" and "have a negative effect on a child born from such a union (44)."

After listing the frames of mind and their possible consequences (i.e. children of hate [the husband hates the wife]; children of intoxication [his/her intention is for the physical act only]; children of coercion [relations against the woman's will]; and children of exchange [the man imagined that he was with another woman]), the authors note the following on a separate page:

An elaboration of the subject discussed in Chapter 9 of Book Two is available upon request. Due to the intimate nature of the material, this 12-page appendix is available only by mailing the original coupon below (no photocopies accepted).

In this coupon, the man is requested to attest to being "engaged/married and fully understand my [his] responsibility to treat this material with discretion (45)."

There are differences between Israeli and American Haredim regarding the topics perceived as suitable for public discourse. For example, Rabbi Berel Wein, a leading educational figure in American Haredi mainstream circles, and popular speaker and author (46), currently retired and residing in Jerusalem, is promoting the sale of a series of audio and videotapes on various topics through his Destiny Foundation. A series of seven audiotapes discussing "The Changing Role of Jewish Women" includes the topics "Abuse" and "Divorce (47)." So far, no evidence to the existence of any public discourse on such topics among Israeli Haredim has been found; nevertheless, these problems have gained rising attention among Haredi professionals and leaders over the last decade.

(43) Simhah CoHEN, « Mutual Relations in Marriage » [Hebrew], (HCL, JSC 24[1]).

(44) Abramov, Two Halves of a Whole, op. cit., p. 198. The holiness of sexual relations is emphasized in Christian fundamentalist literature as well. For one example, see: Herbert W. ARmstrong, The Missing Dimension in Sex, n.p., 1999 (reprint of the third edition), pp. 71-85.

(45) Idem, p. 201. Certain audiotaped sermons and lectures are also marked as restricted to specific audiences. See: Kimmy CAPLAN, «God's Voice», op. cit., pp. 259-260.

(46) See his widely read and used history books in American Orthodox circles: Triumph of Survival: The Story of the Jews in the Modern Era, 1650-1990, New York, Shaar Press, 1990; Herald of Destiny: The Story of the Jews in the Medieval Era, 750-1650, Brooklyn, Shaar Press, 1993; Faith and Fate: The Story of the Jewish People in the Twentieth Century, Brooklyn, Shaar Press, 2001.

(47) The latter is divided into two parts and spreads over two tapes. For a sales advertisment, in conjunction with The Jerusalem Post, an Israeli daily newspaper in English, see: The Jerusalem Post (July 5, 2001), p. 17. American Orthodox and Haredi circles are engaged in recent years in a public discourse regarding sexual abuse in their communities. For one illustration, see: Julie WIENER, " Orthodox World Grapples with Sexual Abuse », The Jewish Advocate 192[33] (August 17-23, 2001), pp. A5, A33. 


\section{Women's work outside the home: a new approach ?}

One of the main issues that highlights Israeli Haredi women's internal discourse in recent years is: What should be the right attitude toward women's work outside the home? Based upon some representative sources, the following discussion will argue that there are new approaches to women's work outside the home which somewhat contradict those of previous decades. It should be noted that the issue of women's roles preoccupied American Haredim in the early 1970s if not earlier. However, due to the different social and cultural environments on either side of the Atlantic Ocean, the American and Israeli discussions differ in many ways (48).

First and foremost, we must pay attention to a central aspect that is absent from the contemporary discourse, and therefore a historical note is in place. The Beit Ya'akov Haredi women's schooling system was founded in Cracow, Poland, in 1917, with the blessing of Rabbi Yisachar D. Rokah (1854-1927), the spiritual leader of the Belz Hasidim. The idea was to establish a formal school system for Haredi young women, unprecedented at the time in Haredi circles (49), which would prevent religious young women from studying in non-Jewish institutions. These institutions were perceived as inappropriate, dangerous and "rebellious" environments influenced by European culture (50). The goal of Beit Ya'akov was to encourage women to study general subjects, but Haredi rabbinical authorities would closely supervise the content of the courses. This religious schooling system gradually developed over the years in both Eastern Europe and, as of the early 1930s in Palestine as well, and today it represents a vast organization including schools and teachers' seminars, which, in recent years, have gained government and partial academic recognition. Furthermore, the range of topics that are taught in the Beit Ya'akov schools is continuously expanding (51).

The ideological foundation for Beit Ya'akov in Palestine was set forth by Rabbi Abraham Y. Karelitz (1879-1953), known by the acronym Hazon Ish (52), and

(48) See, for example: Nisson Wolpin, « Jewish Women in a Torah Society: for Frustration ? or Fulfillment? », The Jewish Observer, 10 (5-6), November-December 1974, pp. 12-19, and the « Letters and Responses » in Idem 10 [7] (January 1975), pp. 3-7.

(49) Cheders for girls existed in Eastern Europe before the First World War, and they probably set the grounds for Beit Ya'akov. See: Avraham Greenbaum, "'Girls' Cheder' and Girls in Boys' Cheder in Eastern Europe before the First World War » in Immanuel EtKes and Rivka FeldhaY, eds., Education and History: Cultural and Political Contexts, Jerusalem, Zalman Shazar Center, 1999 [Hebrew], pp. 297-305; Shaul STAMPER, «Gender Differentiation and Education of the Jewish Woman in NineteenthCentury Eastern Europe », Polin, 7, 1992, pp. 65-66.

(50) Friedman, « The Ultra-Orthodox Woman » (1995), op. cit., pp. 275-276. For quantitative data, see: STAMPER, "Gender Differentiation and Education », pp. 78-80.

(51) A full account of Beit Ya'akov does not exist, especially regarding the last decades of the twentieth century, but many important details and processes appear in: FrIEDMAN, The Haredi Woman, pp. 4-15; WeIssman, «The Education of Religious Girls »; Idem, « Bais Ya'akov as an Innovation in Jewish Women's Education: A Contribution to the Study of Education and Social Change », Studies in Jewish Education, 7, 1995, pp. 278-300.

(52) We lack an historical-critical account of his life and writings. Nevertheless, some important aspects are discussed by Heilman and Friedman, "Religious Fundamentalism and Religious Jews ", pp. 229-233; Lawrence KaPlan, " Hazon Ish: Critic of Traditional Orthodoxy » in Jack WerTheIMER, ed., The Uses of Tradition: Jewish Continuity in the Modern Era, New York-Jerusalem, The Jewish Theological Seminary of America, 1992, pp. 145-174. 
Rabbi Abraham Y. Wolf (?-1979), a product of German-Jewish Orthodoxy who, after studying in Rabbi Esniel Hildesheimer's rabbinical seminary in Berlin (53), immigrated to Palestine in the 1930s. The ideal presented to these women was to enter the work force in order to allow their husbands to devote all their time to studying traditional religious texts. By providing income for their families, women were regarded as equal partners in the spiritual-religious benefits awarded to their husbands (54). This approach, enthusiastically accepted by Haredi women, enabled the establishment and growth of the Ashkenazi Haredi "Society of Learners" (Hevrat Halomedim) (55).

Overall, this "equal profit distribution" idea regarding working women and learning men is absent in contemporary sermons and lectures to Haredi women. It is interesting to note that this argument has not appeared in the female gatherings examined thus far, in which a speaker addressed women's work, their role and domestic obligations. In other words, the religious framework set forth in order to justify and give meaning to women's work from the 1930s to the $1960 \mathrm{~s}$, is replaced by a diverse set of arguments and approaches.

We must keep in mind that popular speakers and lecturers are, for the most part, well attuned to human needs and dilemmas. Otherwise they would not be popular. Consequently, it appears that the original ideology does not satisfy the average Haredi working woman in Israel, and other explanations and arguments are needed. As we shall see, some of the speakers develop lines of thought which contradict the conservative Haredi rhetoric and certain stereotypes commonly held regarding the way Haredi society deals with gender issues. Furthermore, one can occasionally find words of criticism directed at the Haredi official rhetoric regarding women's roles. For example, psychologist Dr. Ilanah Israel, a graduate of the Hebrew University of Jerusalem who completed her Ph.D. at an American university, chooses to start a series of lectures by noting out the stress that Haredi women encounter as a result of high, at times unrealistic, demanding expectations as well as the atmosphere created by this rhetoric, and the damages it causes (56).

If fifty years ago the main goal was to convince Haredi women about the importance of their work in sustaining the family, now the focus is on the right attitude women should adopt vis-a-vis work. It seems as though Rabbi Hayim Vosner, a popular speaker who is part of the Hungarian Haredi group, explained the crux of the issue, which, in his opinion, is a "bacterium from the street, from the free (=secular) world." After praising Haredi women for contributing to the growth of thousands of learners, rabbis, and noted scholars, he proceeds to argue that "things should be placed in the right perspective: The issue of going out to work is a necessity, but we must know that it is a secondary role and not a primary role." Or, as an

(53) On this seminary, see: Mordechai Breuer, Jewish Orthodoxy in the German Reich, 1871-1918, Jerusalem, Zalman Shazar Center, 1990 [Hebrew], pp. 118-131; David ElLenson, Rabbi Esriel Hildesheimer and the Creation of a Modern Jewish Orthodoxy, Tuscaloosa-London, The University of Alabama Press, 1990, pp. 115-166.

(54) Friedman, «The Ultra-Orthodox Woman ", op. cit., pp. 283-284.

(55) This phenomenon was uncovered, characterized, and described by Menachem Friedman, The Haredi (Ultra-Orthodox) Society: Sources, Trends and Processes, Jerusalem, The Jerusalem Institute for Israel Studies, 1991 [Hebrew], pp. 70-88.

(56) Ilanah IsRAEL, « Woman of Valour and Myself » [Hebrew], No. 1. 
author of a popular Haredi book put it: "The Main role of the married woman is to run the home, to help her husband, and to bring up her children (57)."

After explaining that women's work, which originally was a means, has become a goal in itself, Vosner concludes that:

All this forgery, that women can rarely feel spiritual gratification, to feel fortunate and that they did something, if they did not go out to work, if they stayed at home, if they attended to the family. This is a bacterium, a disorder that penetrated our world from the outside world, from the free (=secular) world (58).

In other words, there is an ongoing shift of Haredi women from perceiving work as an occupation to viewing it as a career. Furthermore, it seems as though Vosner and many others understand that the battle over "the letter of the [religious] rule" is apparently lost, and the aim is to keep its spirit from being violated (59).

Rabbi Eliezer Ben David adds another dimension to the problem, namely that men devote themselves to religious studies and women engage in general studies. According to Ben David,

The girls [who] learn at Beit Ya'akov, thank God, learn at the seminaries, learn psychology, learn many things, know a great deal, know many issues that the [male] youth do not know - did not learn and do not know... Suddenly this woman comes, she understands everything, knows everything... sees her husband, he does not understand this, does not understand that, and she is wise and even a teacher, so she - the first student she wants to attend to is her husband... she will educate him: listen, one does not eat like this, don't make a noise [when you eat], why are you chewing too much - the voice of your mouth can be heard, you don't hold a knife like this. You are laughing, I think that there are many problems like this (60).

Ben David emphasizes that the problems originate from the different educational systems of men and women, and not only from women's perceptions of work. This educational gap seems to affect family life, the roles of the sexes, and the relations between spouses.

These effects can be observed in many levels of Haredi life. For example, there is a significant rise in the number of men who sit in public health service centers during the morning hours with their children who need medical attention. The reason for this rise is the increasing numbers in recent years of Haredi women working in jobs outside their community, whether in a government office, dental clinic, or a legal/accounting firm. These women must be at work by a certain hour or else they will be fired, something the family cannot afford (61). The reality of working women has taken preference to men's continuous obligation to engage in religious studies, which, in the Haredi interpretation of religious law, should overrule almost all other religious obligations.

(57) Saul Wagschal, Taharas and Kedushas Am Yisroel: A Guide to Marriage Rights and Obligations and Family Life, Part 2, Jerusalem-New York, Feldheim, 1997, p. 121. In addition, see: Frieda Bernstein, "The Socialization of Girls in an Ultra-Orthodox Community » in Yitzhak Kashti and Mordecai ArieleI, eds., Residential Settings and the Community: Congruence and Conflict, London, Freund, 1987, p. 20; Esther Jungreis, The Jewish Soul on Fire, New York, William Morrow, 1982, pp. 136-139.

(58) Hayim vosner, «The Main Duty of the Woman » [Hebrew] (HCL, JSC 188-1).

(59) These terms are borrowed from Ammerman, Bible Believers, op. cit., p. 137.

(60) Eliezer Ben David, « Domestic Happiness No. 2 » [Hebrew].

(61) For a detailed and practical account of the assistance that the husband should give at home, see: Conen, The Jewish Home, 2, op. cit., pp. 64-68, 74-80. 
Both male and female preachers address the proper attitude women should have regarding their work. For example, in a series of lectures to women on various issues relating to women's roles, obligations, and personal attributes, Rivah Lapidot discusses "the attitude to my work outside the house." According to Lapidot, the first question a woman should ask herself is: "Is my work designated for me ?" If the answer is positive, "I must define clear borders for myself in order not to harm my real mission." In her eyes, a woman must honestly assess her role in building the home, and not look for easy solutions.

Lapidot raises several questions that working women should address: "Even if my exclusive dominions in the house, such as: a clean and orderly house, laundry, sewing, ironing, cooking, baking..., are all taken care of in the best possible way, even then there is a place for a honest and consistent examination: Am I fulfilling my role as a woman? Am I fulfilling my role as a mother in educating the children ?" The reason for asking these questions is the fact that "it is clear to us beyond doubt that the heavenly court will not relate to our work outside the home, even if it is value-motivated." However, "I will be asked did I fulfill my role as a proper woman, a Jewish mother, and only on this will I [be asked to] account for because only I can fulfill these missions (62)."

Lapidot understands that she cannot stop women from seeking work and therefore she focuses on demanding them to engage in constant moral introspection (63). Her last words, however, allude to something much deeper. Similar to other fundamentalists' perceptions, Haredi speakers devote considerable energy to biological and personality differences between men and women, as part of God's creation, which have direct implications on their roles, capacities and natural tendencies (64). For example, Rabbi Simhah Cohen states, "God created woman with a motivation to enjoy dealing with the home" (65), Rabbi Reuven Elbaz explains that the woman does not admire what you [the man] do... The man admires tasty food or tasty wine. What excites the woman? Beautiful jewelry, beauty. A nice dress, something beautiful"; (66) Peninah Elkarif focuses on different levels of emotional sensitivity between the sexes, and argues that men are strong in vision, the big picture, whereas women are strong in the details (67); and Rivah Lapidot states that "we [women] are sensitive, with delicate skin, feel every small offense, receive with the most sophisticated radar any possibility of imaginary offense. For us, due to our intense imagination, things which are possible become real."

One would probably not be surprised to hear such statements from Haredi as well as other fundamentalist speakers and preachers. But based upon them, we find

(62) Rivah LAPIDOT, «The Words of Rivah Lapidot» [Hebrew] (HCL, JSC, 189[104]).

(63) Rabbi Yitzhak Perez, «The Status of the Woman in Judaism » [Hebrew] (HCL, JSC 218[6]), is more direct when he speaks about «women who think about themselves all the time ». Hear also: Peninah ElKarif, "The Wholeness of the Jewish Home in Face of the Salary Chit » [Hebrew] (HCL, JSCA 26[3]).

(64) Armstrong, The Missing Dimension in Sex, op. cit., pp. 90-92; FriedL, « Ideal Womanhood in Postrevolutionary Iran », op. cit., pp. 151-153.

(65) Simhah CoHEN, "Partnership in Marriage » [Hebrew] (HCL, JSCA 24[7]).

(66) Reuven Elbaz, "The Relation Between Man and His Wife » [Hebrew] (HCL, JSC 231). See also Wagschal, Taharas and Kedushas Am Yisroel, Part 2, p. 106.

(67) Peninah Elkarif, « Who am I in My Home? The Way to Know My Place: From Competition to Harmony » [Hebrew] (HCL, JSCA 26[2]). Along similar lines, WAGSCHAL, Taharas and Kedushas Am Yisroel, op. cit., pp. 99-100;102-107, emphasizes that women are emotional and men are rational. 
the argument that a female should not leave domestic and educational responsibilities to a male since he is less qualified to deal with them. For example, Rabbi Simhah Cohen explains that the "stature of speech among men and women is completely different." Whereas men perceive speech as a practical tool, women see it as something higher which has deeper meaning. He notes that women tend to complain about people - usually men - who do not know how to express themselves. After emphasizing the critical importance of speech in a child's development, Cohen concludes that if women were not developed in speech," "the level of our children would be ten times lower than what it is today (68)." According to this contention, if the husband would raise the children, their speech development would be inferior.

This approach helps explain the fact that members of the Haredi Ashkenazi Mitnagdic camp have become more demanding that both male and female toddlers and young children need a female kindergarten teacher during these formative stages of development, which would function as a "mother" substitute. This, until age three when the male identity is restructured (69).

The interesting part of this argument regarding women's superiority is that women are urged to focus on domestic and educational responsibilities not only due to their capacities (70), but rather because they can do them better than men. In other words, a woman's huge advantage over a man in various areas of life serves as the basic argument to persuade her not to abandon domestic responsibilities. The nature of this argument differs from the original argument regarding women's responsibilities, which, as mentioned earlier, was based primarily upon their inferiority regarding the obligation and ability to study traditional religious texts. It seems reasonable that the "you are better than he (is)" argument is more appealing to a working woman, who gains the confidence and appreciation of her superiors as well as discovers career possibilities in which her attributes are not associated with her biological or emotional makeup. This argument focuses on a woman's inner strengths, and not on her "scholarly inferiority to men."

Another aspect that disappears in this line of argument, although not always consciously, is the submissiveness of women, which is an important part of fundamentalist women's self-perception (71). In this case, she is the one who decides, based upon her self-worth and understanding of her talents, qualities and advantages (72).

It is important to note that the discourse regarding women's work does not focus only on the attitude women should have toward work and career. It includes advice on many pragmatic aspects regarding the work environment and its possible

(68) Simhah CoHen, « Dialogue in Marriage » [Hebrew] (HCL, JSCA 24[3]).

(69) Bilu, « Circumcision, the First Haircut and the Torah », op. cit., pp. 50-55.

(70) For a description of female capacities in a popular newsletter for Haredi women, see: BERNSTEIN, "The Socialization of Girls in an Ultra-Orthodox Community », op. cit., pp. 20-21.

(71) Ammerman, Bible Believers, op. cit., pp. 140-142; Maldonado, « Building Fundamentalism from the Family », op. cit., pp. 229-230.

(72) It seems as though this change in approach helps explain the fact that popular preachers and lecturers seem to reject voices which supposedly raise delicate topics, such as family planning and abortions. Apparently, women find it difficult to hold full-time jobs, give birth at a high frequency, and handle their growing domestic and educational responsibilities. Hear, for example: Rivah LAPIDOT, « The Words of Rivah Lapidot» [Hebrew] (HCL, JSC 189[907]). 
dangers. For example, Rabbi Wagschal points out that women who are "required in the workplace to have dealings with men, and even to give them orders," must "develop a dominant strain, which is in direct contradiction to the quality of modesty." Furthermore, "a woman who goes out to work wants to dress attractively and wear jewellery (sic). If she does so, she ends up dressing in order to create an impression on others rather than for her husband alone." In addition, "she is inadvertently arousing the impulses of the men at work (73)."

Finally, it is worth mentioning an argument used by American Christian fundamentalists, in their attempts to persuade women to "return to the home" and raise their children. According to one writer, an extensive ten-year study, conducted by the National Institute of Child and Human Development in ten American cities, "found that 17 percent of children who spent 30 hours a week or more in day care exhibited more aggression and behavioral problems than those who spent less than ten hours away from mom." In addition, failure to create high quality child care environments, questions raised regarding the possible uneasily measured problems the other eighty-three percent of preschoolers may have, rejection of the importance of social development at this young age, and emphasizing the importance of emotional development until age three - all lead to the essential and irreplaceable role of motherhood (74). This argument has not been found in the Israeli Haredi popular discourse examined so far.

\section{Family purity laws: new justifications?}

The need for new arguments is apparent in other areas of Haredi female internal discourse as well. For example, the use of scientific findings in order to encourage women to observe family purity laws (75). To be sure, the use of scientific findings and rationalization in connection with family purity laws is not a contemporary Haredi invention (76). It has been traced, among other cases, in the first half of the twentieth century in American Jewish circles (77). Furthermore, the use of

(73) Wagschal, Taharas and Kedushas Am Yisroel, Part 2, op. cit., p. 122.

(74) Ryan Malone, « No Place Like Home», The Philadelphia Trumpet, July 2001, The Philadelphia Church of God, Edmond, OK, pp. 29-30.

(75) The basic law, according to Jewish Orthodox/Haredi interpretation, is that sexual intercourse is prohibited from the moment blood is seen until a period of seven days after the bleeding has ceased. In addition, sexual relations must not begin before the woman attends a ritual bath. For a basic summary of this interpretation of the law, and the practical details and considerations involved, see: Tehilla ABRAMOV and Malka Touger, The Secret of Jewish Femininity: Insights into the Practice of Taharat HaMishpachah, Southfield, Targum Press, 1988, pp. 54-97, 134-146. Most discussions on purity laws in recent years lead back to Mary Douglas's Purity and Danger: An Analysis of Concepts of Pollution and Taboo, London, Routledge and Paul Kegan, 1966. For a compilation of articles with different approaches, see: Marcel Poorthuis and Joshua Schwartz, eds., Purity and Holiness: The Heritage of Leviticus, Leiden, Boston and Koln, Brill, 2000.

(76) Shifts in rhetorical tactics to rationalizing arguments are a phenomenon much beyond the religious sphere. See, for example: Joel Best, Threatened Children: Rhetoric and Concern about Child-Victims, Chicago-London, Chicago University Press, 1990, pp. 22-45. However, they deserve special attention when they appear among groups who have an agenda of returning to tradition and the divine word.

(77) Beth S. Wenger, «Mitzvah and Medicine: Gender, Assimilation, and the Scientific Defense of 'Family Purity' ", Jewish Social Studies, 5 (1-2), 1998-1999, pp. 177-203. 
science in order to sustain religious practice appeared during this period in other discussions of religious observance, such as circumcision (78). However, as we shall see, the social and historical context we are dealing with is somewhat different.

Similar to other fundamentalist societies, Haredim are characterized by an ambivalent, love-hate approach to modern science (79). Thus we can find a complete rejection of academic approaches, assumptions and conclusions, an almost obsessive need to confront academic works and prove them wrong, and an occasional use of scholarship as proof for the truth or triumph of religion - all at the same time. This ambivalent approach leads to certain levels of internalization and acceptance of academic lines of thought which, at times are unconscious, alongside continuous rejection of them (80).

In the case of family purity laws, we observe significant use of academic research and findings, and it seems as though male lecturers and preachers use this line of argument more frequently. Rabbi Reuven Elbaz, one of the most central figures in the repentance (hazarah biteshuvah) movement among Sephardi Haredim (81), addresses the importance of family purity laws in a lecture entitled "Happy and Healthy Marriage (82)." Elbaz starts by arguing that divine laws and rules of family purity are inexplicable in logical terms and points to their importance as well as to the severe punishment of women who do not observe them. Moments later he focuses on modern research, which, in his opinion, provides us with the necessary proof regarding the advantages of observing purity laws.

Elbaz states that "great doctors, illustrious professors, have conducted a lot of research on the woman's body, woman's illnesses, man's illnesses, children's illnesses... mental illnesses, physical illnesses... [they] found that great benefit can be derived from this precious commandment." He argues, "this is the reason, according to doctors and scholars, for many kinds of hard illnesses that exist in modern society." Elbaz continues to quote Doctor Vineberg from "Monti [sic. =Mount] Sinai Hospital in New York, who claimed "ovarian cancer appears among non-Jewish women twenty times more than among Jewish women (83)."

(78) David L. Gollaher, « From Ritual to Science: The Medical Transformation of Circumcision in America », The Journal of Social History, 28 (1), 1994, pp. 5-37.

(79) See, for example: George M. MARsDen, Fundamentalism and American Culture: The Shaping of Twentieth-Century Evangelicalism, 1870-1925, New York-Oxford, Oxford University Press, 1980, pp. 18-21, 57-62, 212-221; Everett Mendelsohn, «Religious Fundamentalism and the Sciences » in Marty and Appleby, eds., Fundamentalisms and Society, op. cit., pp. 23-42; James Moore, "The Creationist Cosmos of Protestant Fundamentalism », Idem, pp. 42-73; Bassam TiBI, "The Worldview of Sunni Arab Fundamentalists: Attitudes toward Modern Science and Technology », Idem, pp. 73-103.

(80) Haredi approaches to and uses of science vary and deserve a thorough examination. See, for example: Yoram BILU and Yehuda Goodman, « What Does the Soul Say?: Metaphysical Uses of Facilitated Communication in the Jewish Ultraorthodox Community », Ethos, 25 (4), 1997, pp. 375-407; Kimmy CAPlan, « Have 'Many Lies Accumulated in History Books'?: The Holocaust in Ashkenazi Haredi Historical Consciousness in Israel », Yad Vashem Studies, 29, 2001, pp. 321-376.

(81) On his work with Sephardi prisoners in Israeli jails, see: Janet AVIAD, Return to Judaism: Religious Renewal in Israel, Chicago, Chicago University Press, 1983, pp. 42-45.

(82) HCL, JSC 232 Hebrew].

(83) On Dr. Hiram Vineberg and his study from 1919, see: Wenger, « Mitzvah and Medicine », pp. 181-182. 
It should be noted that this popular concept appears in numerous Haredi sources. For example, Abramov and Touger state that "a number of medical studies of the incidence of cervical cancer show that it can occur as much as twenty times more frequently among women who don't practice Taharat HaMishpachah [family purity laws] than among those who do (84)."

Toward the end of his presentation, Elbaz returns to quoting doctors and gynecologists who have proved that women's hormones during their menstruation period can be physiologically harmful, and even destructive (85). Elbaz concludes that observance of family purity laws explains the fact that divorce rates among observant Jews are much lower than in general society.

In other words, if at the beginning of his lecture the commandments regarding purity laws of sexual intercourse were presented as illogical, now, thanks to modern scientific research, they are completely logical.

Similar lines of thought can be found in Dr. Eli Schusheim's lecture in Hebrew to senior, female high school Haredi students on "Health and Happiness in Marital Life (86)." Schusheim is considered a medical authority in many Haredi mainstream circles, especially on aspects of marital relations, abortion etc (87).

Schusheim opens by stating that Jews observed family purity laws throughout the generations, in many cases in the most difficult situations, at times more than any other commandment. "The archaeologists, among them the most well-known: Yigael Yadin [1917-1984], who dug under the earth and found remnants of Jewish settlement[s], the most remarkable [of them] was at Masada, when he wants to prove that in a certain place there was a Jewish settlement, the clear-cut proof in these cases is the existence of a ritual bath (88)."

After emphasizing the importance of family purity laws, with the help of archaeologists and archaeological findings - which the Haredim usually abhor Schusheim argues that, by definition, all religious laws for people must be in line

(84) Abramov and Touger, The Secret of Jewish Femininity, p. 50. See also: Naomi Marmon, «Reflections on Contemporary Miqveh Practice» in Rahel R. WASSERfall, ed., Women and Water: Menstruation in Jewish Life and Law, Hanover-London, Brandeis University Press, 1999, p. 239.

(85) See also: Abramov and Touger, The Secret of Jewish Femininity, p. 49. The focus on the "unclean state of women's internal parts" during a woman's menstrual period has some especially colorful expressions in Sephardi Haredi popular literature. One can find texts that describe a woman's body with images of snakes, worms and other creatures crawling around, which disappear after this period ends and the woman dips in a ritual bath. Finally, perceptions regarding mentrual blood being dirty and poisioning are not unique to Haredim or believers in general. See, for example: Sophie LaWs, Issues of Blood: The Politics of Mentruation, London, Macmillan, 1990, pp. 32-37; David I. MACHT, « Further Historical and Experimental Studies on Menstrual Toxin », The American Journal of the Medical Sciences, 206, 1943, pp. 281-305.

(86) HCL, JSC 198(1).

(87) He heads the non-political organization "Efrat", that seeks to "promote higher Jewish birthrates, prevent abortions, and strengthen the family unit in Israel." See: Eli Y. SchUsheIM, Toward a Happy Marriage, Jerusalem, The Medical Section of Efrat, 1984 [Hebrew].

(88) Abramov and Touger, The Secret of Jewish Femininity, op. cit., pp. 126-127, also use Masada as an illustration, although in a slightly different context. The use of Masada is especially interesting due to its centrality in the Zionist and Israeli collective memory. See: Nachman BEN-YeHUDA, The Massada Myth: Collective Memory and Mythmaking in Israel, Madison, University of Wisconsin Press, 1995. Finally, although a ritual bath documents Jewish life and settlement, other indications, such as synagogues, Jewish artifacts and Jewish symbols, are necessary and, many times, more common. For example, a ritual bath on its own could be related to the Samaritans. 
with human health. Otherwise, observant Jews would be confronted with a theologically illogical situation in which one is divinely commanded to endanger his/her health.

Even though many non-Jews medically explained the logic of Jewish commandments as stemming from health reasons, Schusheim emphasizes that Jews observe these commandments because of their divine importance and not due to some medical or other logical explanation. The examples he utilizes include circumcision (observed "even in the British royal dynasty"), fasts ("which cleans secretions from the body"), and abstention from pork ("which is well-known to transmit serious diseases"). According to Schusheim, the medical explanation is an added value for the observant Jew (89).

The main part of this lecture is devoted to a rather detailed description of pregnancy and female physiology, to be precise: the womb, menstrual system, ovules, uterine tube, and many other organs. This description leads Schusheim to explain the medical logic which stands behind family purity laws, and how observing these laws prevents cancer of the womb (90). According to Schusheim, this was the most common cancer among women in the world until recently, with the exception of Jewish women. In recent years it is more common among Jewish women precisely because they are less stringent about observing purity laws.

Toward the end of his lecture, Schusheim feels the need to explain why this sensitive topic should now be publicly addressed, despite the fact that it was socially unacceptable in previous generations. His explanation focuses on the "different situation" we are confronting today, but he does not go into details (91).

Be that as it may, the evident Haredi need to employ scholarly findings in order to reinforce strict observance of family purity laws suggests that the influence of the "standard" traditional arguments is in decline and in need of rational reinforcement (92). One of the reasons for this declension is the growing exposure of women to non-religious environments and to general education based upon modern approaches, which, in Haredi eyes, results in the urgent need to protect the perceptions of right and wrong, good and bad. Ultimately, as Mary Douglas has pointed out, these laws serve the cause of maintaining social order in a religious community, especially, we may add, in a community that fosters strong feelings of an existentially threatened minority for nearly two hundred years.

(89) See also: Abramov and Touger, The Secret of Jewish Femininity, op. cit., p. 50; A Honeymoon for Ever: Chapters in Family Purity, n.p., n.d., anonymous [Hebrew], p. 31. For other expressions of this ambivalence, see: Wenger, «Mitzvah and Medicine », op. cit., pp. 196-197.

(90) Certain American Christian fundamentalist popular literature also presents detailed descriptions of female physiology, although obviously in different religious frameworks. However, descriptions of male sex-related physiology, which appear in Christian literature, are absent from the Haredi scene. For one example, see: Armstrong, The Missing Dimension in Sex, op. cit., pp. 93-124, 136-144.

(91) Reuven Elbaz, «The Light of Purity and its Great Importance » [Hebrew] (HCL, JSC 230[2]), also explains that very little has been written on this topic, however "our times demand to even produce audiotapes, to publicize these things... believe me. »

(92) For additional rationalizations of family purity laws by Orthodox women, see: MARMON, «Reflections on Contemporary Miqveh Practice », op. cit., pp. 235-247. 


\section{Conclusion}

It seems as though the internal popular discourse to which mainstream Israeli Haredi women are exposed in recent years is characterized by the use of new arguments and rhetorical tools when addressing delicate issues such as women's work outside the home and the relationship between husband and wife.

The fact that these new arguments and tools come from popular speakers, preachers and literature representing popular Haredi religion is of great importance, especially in a society were rabbinic and spiritual authorities are so central. These feminist-influenced voices do not come from the Haredi spiritual leadership, and, in fact, they quite often contradict what these leaders say and the arguments they use in order to persuade their followers. Furthermore, there is a growing gap between these sermons and lectures and the formal educational Haredi women's system. Whereas in Beit Ya'akov the ideology set forth by Rabbis Karelitz and Wolf continues to be central, notwithstanding the significant changes this institute has undergone over the years, it has been marginalized and, at times, even disappeared from the informal educational system of sermons and lectures.

Another important aspect of this process occurring in the realm of popular religion should be emphasized. Similar to popular entertainers, popular speakers and preachers are not only popular because of how they say things (rhetoric) but also because of the relevance of what they have to say (content). In most cases, a talented speaker does not remain popular if his/her message is irrelevant to his/her listeners. In other words, popular speakers provide us with certain indications about the problems, interests, and dilemmas of their listeners.

Therefore, it seems reasonable to conclude that the relevance of the official ideology that justified women's work, roles and obligations, has decreased considerably over the last twenty years. This ideology does not supply many Haredi women with sufficient answers for coping with their reality as working women as well as the influence of work on their self-image and relationship within the family. Their search for new answers and approaches only increases the more they work in non-Haredi environments. In other words, the more they become acquainted with alternative forms of life, role distributions and relationships between spouses (93), they experience growing difficulty to be "a free-agent and in some cases in charge of others" at work and "readjust to a situation whereby she is subordinate in the home (94)." The popular speakers are providing these relevant answers and approaches, which, on the whole, pay considerable attention to women's sensitivities, qualities and needs, as they perceive them.

This situation seems to indicate that there are contradictions and tensions between Haredi elite and popular religion, which is no surprise to anyone acquainted with historical and contemporary cases of popular religion. But at the same time, we should keep in mind the other side of these different voices. Under the umbrella of the "official" ideology, emphasizing continuity and tradition, there

(93) This general trend is connected with the growing awareness in Israeli Haredi society to domestic problems of exploitation, violence and abuse, as well as juvenile delinquency in recent years.

(94) Wagschal, Taharas and Kedushas Am Yisroel, Part 2, op. cit., p. 122. 
are significant challenges and new situations that need to be addressed, and which is done primarily at the popular level.

Unlike the public discourse in certain fundamentalist groups, which tends to be "masculine" and "man-centered (95)," the tone, content, metaphors and associations in this discourse are, in many cases, feminine. We have traced several basic feminist assumptions and influences within the arguments used in popular Israeli Haredi women's internal discourse. These subtle inferences, often hidden behind rhetorical screens such as counter feminism (96), suggest that preaching does not necessarily remain male centered or oriented in its form and content, even in ultraconservative fundamentalist societies (97). Assuming this is correct, an important question is from where did they come? Unfortunately, an attempt to provide a full answer to this question is beyond both the borders of this article and the expertise of its author. However, we would like to suggest one partial answer that is related to American Haredim.

Even though we lack a comparative study of Israeli and American Haredim, any observer would undoubtedly recognize the differences between these two groups as well as their ambivalent and complex relationships. These differences can be observed, for example, in the dress, talk, leisure habits and level of involvement in the surrounding culture of Israeli and American yeshivah students, and the ambivalence is demonstrated in the attitude of some Israeli Haredim to their American contemporaries (98). Nevertheless, there are growing religious, cultural, and financial contacts and a stream of knowledge from American Haredim to those in Israel and visa versa. Evidence of this process is reflected in the abundant popular literature, published by Targum Press, Feldheim and other publishers, which, as we noted earlier, has been translated into Hebrew or English over the last two decades (99). Furthermore, certain Israeli Haredi female lecturers and preachers are of American origin or have been exposed to and influenced by American Haredi women whom they consider their spiritual mentors (100).

Many American Haredi women are involved in a continuing process of encountering feminism. These women's perceptions of feminism as a strong force in American life, making inroads into Jewish religious circles, led them to conclude that they cannot remain indifferent. By directly confronting feminism, they create a counter-feminist approach that provides answers and explanations. Some of this discourse is characterized by accepting and acknowledging certain virtues of feminism, but at the same time by claiming that these aspects are part and parcel of the Jewish religion.

(95) HARDing, The Book of Jerry Falwell, op. cit., p. 177.

(96) MorRIS, Lubavitcher Women in America, op. cit., pp. 127-128.

(97) Harding, The Book of Jerry Falwell, op. cit., p. 178.

(98) On the latter, see: Samuel HeILman, Defenders of the Faith: Inside Ultra-Orthodox Jewry, New York, Schocken, 1992, pp. 98-99.

(99) See, for example: Abramov, Two Halves of a Whole, op. cit.; Cohen, What Did You Say, op. cit. This phenomenon is apparent in other topics as well, such as Haredi popular literature on the Holocaust. For one example, see: Pearl Benish, To Vanquish the Dragon, Jerusalem-New York, Feldheim, 1991 (Hebrew ed.: Haruah Shegaverah Al Haderakon, Jerusalem and New York, Feldheim, 1993).

(100) One source of influence is Esther Jungreis, a Holocaust survivor born in Szeged, Hungary, who was in the Bergen Belsen camp. According to JungreIs, The Jewish Soul on Fire, op. cit., pp. 11-17, 205-242, her experiences during the Second World War greatly influenced her later activities. 
For example, in an article entitled "Chasidic Feminist," published in the Habad associated quarterly Wellsprings, the author, Rivka Slonim, states that

I feel grateful to the feminist movement for the positive changes it has brought for women. It has brought opportunity, equitable pay and respect to the female half of society. My perception of all this is that the feminist movement has helped society catch up to the Chasidic world (101).

It seems as though certain feminist values and approaches, which have been reinterpreted as existing, at times originating from traditional Judaism, have filtered from American Haredi discourse to the Israeli scene, even though not always consciously or in an orderly way. However, this three-stage connection, i.e. feminist movement-American Haredim-Israeli Haredim, only clarifies in part the possible source of feminist approaches and arguments in the internal discourse of Israeli Haredi women.

Numerous additional questions, complexities and issues regarding this fascinating contemporary phenomenon, such as the perception and meaning of love and romance to the average Haredi male and female, demand and deserve much further attention. However, its existence enables us to explore the nature of change and renewal that occurs in a fundamentalist society that has undergone a conscious process of traditionalization.

\author{
Kimmy CAPLAN \\ Bar-Ilan University, Israel
}

(101) The quotation is based upon the internet version of this article, which appeared in July 2000, at the following site: http: //www.chabad.org. For additional examples, see: Tamar FrankieL, Book Review, Wellsprings, 42, 1995, pp. 36-38; Naftali Loewenthal, "Discovering the Woman Chasid ", Idem, 46, 1998, pp. 28-34; Baila OlidorT, « Coming Full Circle », Idem, 45, 1997, p. 3. 
Over the last twenty years, a popular, internal discourse has developed among Haredi women in Israel. Both male and female speakers and preachers, addressing exclusively female audiences, discuss "traditional" as well as "controversial" issues. This article focuses on three central "controversial" issues raised in their discourse understanding the opposite sex, women's work outside the home, and family purity laws - within several social, historical and methodological contexts. In addition, we examine certain patterns of continuity and change within Haredi internal discourse, as well as draw particular attention to the emergence of feminist ideas within it. The popular sources and materials related to in this article enable us to highlight a number of comparisons and mutual influences between contemporary Israeli and American Haredim, an aspect yet to be researched systematically.

\section{Résumé}

Ces vingt dernières années, un discours populaire interne s'est développé chez les femmes ultra-orthodoxes israéliennes. S'adressant exclusivement à un public féminin, les orateurs et prédicateurs - hommes ou femmes - abordent des problèmes aussi bien 'traditionnels' que 'controversés'. Cet article traite de trois problèmes 'controversés' évoqués dans leurs discours - compréhension du sexe opposé, travail de la femme à l'extérieur et lois juives relatives à la pureté familiale - dans divers contextes sociaux, historiques et méthodologiques. De plus, nous étudions certains schémas de permanence et d'évolution à l'intérieur du discours ultra-orthodoxe, en y soulignant tout particulièrement l'émergence d'idées féministes. Les sources et matériaux populaires utilisés dans cet article nous ont permis de mettre en relief des comparaisons et influences réciproques entre les ultra-orthodoxes israéliens et américains d'aujourd'hui, problématique qui n'a pas, à ce jour, fait l'objet de recherches systématiques.

\section{Resumen}

Durante los últimos veinte años, un discurso popular e intrínseco se desarrolló entre las mujeres ultraortodoxas israelies. Dirigiéndose exclusivamente a un público femenino, los oradores y predicadores - hombres o mujeres - abordan problemas tanto 'tradicionales' como 'controvertidos'. Este artículo trata tres problemas 'controvertidos' evocados en sus discursos - comprensión del sexo opuesto, trabajo de la mujer en el exterior y leyes judias relativas a la pureza familiar -, en diversos contextos sociales, históricos y metodológicos. Además, estudiamos ciertos esquemas de permanencia y de evolución al interior del discurso ultraortodoxo, destacando particularmente la emergencia de ideas feministas. Las fuentes y materiales populares utilizados en este artículo nos han permitido enfatizar comparaciones e influencias reciprocas entre los ultra-ortodoxos israelies y americanos de hoy, problemática que no ha sido, hasta hoy, objeto de investigaciones sistemáticas. 
